\title{
Governing Knowledge
}

\section{The Strategic Human Resource Management Dimension}

Foss, Nicolai Juul; Minbaeva, Dana

Document Version

Final published version

Publication date:

2009

License

CC BY-NC-ND

Citation for published version (APA):

Foss, N. J., \& Minbaeva, D. (2009). Governing Knowledge: The Strategic Human Resource Management

Dimension. Center for Strategic Management and Globalization. SMG Working Paper No. 3/2009

Link to publication in CBS Research Portal

\section{General rights}

Copyright and moral rights for the publications made accessible in the public portal are retained by the authors and/or other copyright owners and it is a condition of accessing publications that users recognise and abide by the legal requirements associated with these rights.

Take down policy

If you believe that this document breaches copyright please contact us (research.lib@cbs.dk) providing details, and we will remove access to the work immediately and investigate your claim. 
Governing Knowledge: The Strategic Human Resource Management Dimension

Nicolai J. Foss

Dana B. Minbaeva

SMG WP 3/2009

March 5, 2009 
SMG Working Paper No. 3/2009

March 5, 2009

ISBN: 978-87-91815-44-7

Center for Strategic Management and Globalization Copenhagen Business School

Porcelænshaven 24

2000 Frederiksberg

Denmark

www.cbs.dk/smg 
GOVERNING KNOWLEDGE:

THE STRATEGIC HUMAN RESOURCE MANAGEMENT DIMENSION

\author{
Nicolai J. Foss \\ Center for Strategic Management and Globalization \\ Copenhagen Business School \\ Porcelaenshaven 24, 2000 Frederiksberg; Denmark \\ njf.smg@.cbs.dk \\ and \\ Department of Strategy and Management \\ Norwegian School of Economics and Business Administration; \\ Breiviksveien 40; N-5045 Bergen; Norway
}

Dana B. Minbaeva

Center for Strategic Management and Globalization

Copenhagen Business School

Porcelaenshaven 24, 2000 Frederiksberg; Denmark

dm.smg@cbs.dk

March 1, 2009

\begin{abstract}
SHRM increasingly emphasizes HRM practices as means to build strategic knowledge resources such as superior capabilities. While the knowledge-based view increasingly pays attention to micro-foundations, the SHRM field neglects these and emphasizes collective constructs such as "human capital pools," "HRM architectures", etc. As a result, causal links between HRM practices, knowledge and organizational performance are black-boxed. We propose a program for research and identify some of the key issues that future research must deal with.
\end{abstract}

Keywords: Knowledge, HRM practices, architectures, micro-foundations, levels of analysis.

Acknowledgement: We thank (without implicating) Patrick Wright, Susan Jackson, Brian Becker, Shad Morris and Henrik Holt Larsen for discussions of the issues treated in this paper and comments on an earlier version of the paper. 


\section{INTRODUCTION}

"Knowledge" in various forms and at various levels has become a central construct in a broad range of fields in management research (Grandori \& Kogut, 2002). The driver behind this expansion of interest arguably is that the management and governance of knowledge has become a critical issue for financial, innovation and growth performance, competitive dynamics, international strategy, the building of resources, the boundaries of firms, and many other issues. What may be called "knowledge performance" has become a crucial intermediate performance variable, anteceding financial performance. Accordingly, much research — characterized as the "knowledge movement" by Eisenhardt and Santos (2003) — has been undertaken on processes of sourcing, building, sharing, transferring, and integrating knowledge within and between organizations (henceforth, "knowledge processes").

Much of this work has been conceptual/definitional and taxonomic; however, an accumulating body of theoretical and empirical work examines the antecedents and outcomes of knowledge processes. Concerning antecedents knowledge-based scholars are increasingly turning their attention to the organizational mechanisms that may determine, mediate, or moderate knowledge processes (e.g., Grant, 1996; Osterloh \& Frey, 2000; Grandori \& Kogut, 2002; Eisenhardt \& Santos, 2003; Minbaeva, Pedersen, Bjorkman, Fey \& Park, 2003; Nickerson \& Zenger, 2004; Janssen, van den Bosch \& Volberda, 2006). Furthermore, knowledge-based scholars increasingly pay attention to the linkages between the organization or collective level, and the levels of individual action and interaction. This is based on the premise that truly

\footnotetext{
1 "Knowledge performance" is a portmanteau term that covers organizational-level outcomes of organizational knowledge processes, such as knowledge sharing, knowledge transfer, knowledge building, knowledge acquisition, etc.
} 
understanding (beyond correlation) relations between organizational antecedents and knowledge performance (Grandori \& Kogut, 2002) implies theorizing the individuals (Grant, 1996), individual heterogeneity (Felin \& Hesterly, 2007), and individual interaction (Felin \& Foss, 2005) that mediate these relations.

The human resource management (HRM) field, and particularly its strategic HRM (SHRM) sub-field, is no exception to the overall expansion of interest in knowledge processes and their organizational antecedents (cf. Wright, Dunford \& Snell, 2001). In fact, because of its concern with the identification (recruitment), development (training), deployment (staffing), and remuneration (rewards) of human capital (i.e., knowledge embodied in humans) and its services, the SHRM field would seem to speak directly to micro-, individual-level issues relating to the governance of knowledge. Indeed, it is arguable that for this reason, SHRM has the potential to constitute parts of the micro-foundations for work on the link between firm-level knowledge assets (e.g., capabilities) and overall performance (Felin \& Foss, 2005; Felin \& Hesterly, 2007; Teece, 2007; Felin, Tomsik \& Zenger, 2008).

However, this potential is not being realized at the moment. Up till now, the SHRM field has taken a more collective level (aggregate, reduced form) approach, reasoning in terms of "human capital pools," "systems for managing people," and "HRM architecture", which are posited to somehow directly influence knowledge performance. For example, an important research issue in the knowledge movement has been the importance of stickiness as a barrier to knowledge transfer (Szulanski, 1996). While SHRM scholars have certainly examined the stickiness of HRM practices (e.g. Ferner, Almond \& Colling, 2005), they have not examined how HRM practices may be deployed in order to decrease stickiness, nor - and more to the point in the present context - have they included stickiness on the level of individuals or shown 
how stickiness may result from individual behavior. This may be seen as an example of the tendency in the knowledge-based view to place the locus of knowledge at the collective level (i.e., capabilities - or "human capital pools," etc.) and suppress the level of individuals as the relevant locus (Felin \& Hesterly, 2007). Because little attention is paid to the level of individuals, it is not too unfair to characterize the treatment of the linkages between HRM practices and organizational performance as a black box. Useful articulation of this black box is "the most pressing challenge facing SHRM" in its attempt to understand "the strategic logic between a firm's HR architecture and its subsequent performance" (Becker \& Huselid, 2006: 899).

A growing body of empirical work (e.g., Minbaeva et al., 2003; Laursen \& Foss, 2003; Cabrera, Collins \& Salgado, 2006; Beugelsdijk, 2008) has discussed HRM practices and architectures as means to obtain beneficial outcomes of knowledge processes, such as innovation. As we will indicate below, the existing empirical evidence is, however, ambiguous and not sufficiently informed by theory. For example, empirical researchers do not agree on which HRM practices matter, how they matter, how they should be bundled to achieve maximum impact on knowledge performance, which knowledge processes they may influence, and so on. The existing disagreements are arguably partly caused by insufficient conceptual and theoretical foundations for understanding the links between HRM and the processes and content of organizational knowledge. Theoretical and methodological compasses are missing that can organize empirical research by suggesting potentially fruitful avenues of research.

Accordingly, this paper is a call for building micro-foundations for the HRM-knowledge performance link that are rooted in individual behaviors, knowledge, motivations, preferences, etc., and therefore also in individual heterogeneity (Felin \& Hesterly, 2007). We take such work to consist of the formulation of theories about (latent) mechanisms that can account for empirical 
relationships. Thus, theoretical work in the present context means work that systematically links HRM and knowledge performance in a strategic context, in the sense that it comprehensively identifies and theorizes the relevant causal mechanisms and variables that are involved in arguments that SHRM can cause superior knowledge performance (and overall firm performance). Although a handful of research papers have recently treated these issues (e.g. Felin, Tomsik \& Zenger, 2008), SHRM scholars do not have access to a mapping of existing research on how SHRM connects to knowledge performance. We provide such a mapping as a diagnostic tool to help us identify some of the key but under-researched issues that future research in this important field must deal with.

The paper is structured as follows. In order to provide a basis for the discussion, we first review what has been done to link HRM and knowledge performance. Then we identify research challenges associated with the level of analysis and causal mechanisms. We argue for the need for micro-foundations and put forward a model which specifies the concrete content of such foundations, including the causal mechanisms which bring us from macro to micro and back to macro. We use this model to diagnose in a more precise manner some of the implications for future SHRM research on HRM-knowledge performance.

\section{HRM AND KNOWLEDGE LINKS: LITERATURE REVIEW}

Key theoretical contributions to the SHRM literature have increasingly stressed that significant links exist between HRM and knowledge performance, and, per implication, financial performance (e.g., Lado \& Wilson, 1994; Wright et al., 2001; Lepak \& Snell, 2002; Kang, Morris \& Snell, 2007). In an early contribution, Lado and Wilson suggested that HRM practices "can contribute to sustained competitive advantage through facilitating the development of 
competencies that are firm specific, produce complex social relationships ... and generate organizational knowledge" (1994: 699). As Wright et al. note, this "point of view seems well accepted within the current SHRM paradigm" (2001: 704). In a SHRM perspective informed by the resource-based view (RBV) (Barney, 1991), persistent differences in firm performances are accordingly explained in terms of the extent to which HRM practices create value, are rare, costly to imitate, etc. (Barney, Wright \& Ketchen, 2001). Further, bridging the RBV with SHRM provides "the traditionally atheoretical field of SHRM with a theoretical foundation from which it can begin exploring the strategic role that people and HR functions can play in organizations" (Wright et al, 2001: 716-717). Increasingly, SHRM researchers have gone beyond the RBV to also draw on insights from the related knowledge-based view (KBV) (Lepak \& Snell, 2002; Wright et al., 2001; Kang et al., 2007), including insights into social and organizational capital (idem.; Gittell, 2000). In spite of a growing interest in exploring links between SHRM and knowledge, theoretical contributions, such as the ones just mentioned, are still few in number.

It is not inherently a problem for a field that only relatively few theoretical contributions exist. In fields that are very well established in the sense that fundamental insights and key concepts and causal relations, etc. can reliably be taken as well established, the ratio between theoretical and empirical/applied work may decline over time (Kuhn, 1970). Similarly, the argument may be forwarded that in emerging fields this ratio should be low, as there is a need for much explorative and inductive empirical research (Eisenhardt, 1989). However, without going into the history of the field in any great detail, it seems clear that the SHRM field is neither very well established, nor is it new and emerging (Wright, Gradner, Moynihan \& Allen, 2005). Some insights are rather well established, at least theoretically (e.g., the effect of training on employees' job-related knowledge and the effect of work organization on employees' 
satisfaction), while other insights seem much more preliminary, incomplete, or even speculative (Wright \& Haggerty, 2005; Becker \& Huselid, 2006). In the latter category fall, notably, the micro-foundations for arguments asserting links from HRM to knowledge performance. As we detail later, the whole dimension of what are the causal mechanisms that mediate between HRM and knowledge performance outcomes and how these mechanisms are ultimately rooted in individual action and characteristics, tends to drop out of sight because of the aggregate focus of existing theorizing. Thus, more work needs to be done to increase our understanding of why and how and to what extent HRM and knowledge performance are linked.

Perhaps as a result of the relative sparseness of theoretical work, there is a bias in the existing empirical work. While HRM at large is biased towards cross-sectional, large-N empirical work, empirical research on the importance of HRM for knowledge performane has been mainly based on single or very few cases. The predominance of qualitative over quantitative research methods is - at least in this specific case - an indication that important constructs and the causal relations that link them are still unclear. Small-N qualitative research is particularly justified when the aim is to identify hitherto neglected factors and relations that later in the scientific inquiry may be theorized as variables and mechanisms (e.g., as done by Swart and Kinnie [2003]), or to engage in a dialogue with existing theory in order to ascertain which of a multitude of candidate variables and mechanisms are the relevant ones (e.g., as done by Currie and Kerrin [2003]). Our conjecture is that we observe a prevalence of this kind of empirical research on the HRM-knowledge performance links exactly because of a lack of theorizing on the issue.

Large-N empirical studies examining HRM practices as explanatory variables of knowledge processes are limited in number and explorative in nature. We conducted article title, 
abstract and introduction searches in top-tier management journals (Extejt \& Smith, 1990; Gomez-Mejia \& Balkin, 1992; Johnson \& Podsakoff, 1994, Tahai \& Meyer, 1999) as well as the most influential HRM journals (Caliguiru, 1999; Hoobler \& Johnson, 2004). All identified articles were then checked for the operationalization of HRM practices as explanatory variables of knowledge performance. Articles where HRM practices were included as part of another construct were not considered..$^{2}$ As a result, only 20 papers could be identified and included in Table 1.

\section{Insert Table 1 here}

These contributions indicate that HRM practices constitute a (potentially important) part of the organizational antecedents of knowledge performance. Collectively, they suggest that a nonnegligible part of observed variation in knowledge performance can be ascribed to variation in the employment of HRM practices. However, the papers are not equally comparable, as not all HRM practices receive equal attention, operationalizations of the practices vary, and the relations between the HRM practices and knowledge performance are often black-boxed. Many of the hypotheses tested in the reviewed studies involve complex relationships between variables across levels of analysis (e.g., HRM practices and architectures can belong to different levels of analysis). However, the relevant levels of analysis are all supra-individual. While focusing mainly on collective-level variation does not logically imply that one assumes away individual-

\footnotetext{
${ }^{2}$ For example, in Pak and Pak (2004) the extent of educational programs and overseas training opportunities provided by the company were considered as part of the absorptive capacity concept.
} 
level variation and change, in practice, the individual level is effectively disregarded (for broader discussions, see Dansereau \& Yammarino, 2005; Felin \& Hesterly, 2007; Abell, Felin \& Foss, 2008). In the following, we argue that more attention needs to be devoted to the level of individuals and their interaction, literally the lowest ("rock-bottom") levels of analysis in social science research.

\section{RESEARCH CHALLENGES}

\section{Levels of Analysis and Causal Mechanisms: A Primer}

The emerging argument that HRM practices and/or architectures can be deployed to cause (perhaps probabilistically, cf. Pearl, 2000) certain beneficial knowledge outcomes is one that involves multiple levels of analysis and complicated causal mechanisms (Dansereau \& Yammarino, 2005). To see this, consider Figure 1, which builds on the work of sociologist James Coleman (1990). The diagram in the figure — often called the "Coleman bathtub" — makes a distinction between the macro and the micro level. For example, it may be that the macro level is that of the economy, while the micro level is that of organizations. Or, it may be that the macro level is organizational while the micro level is that of individuals. As shown, there are links between macro-macro (Arrow 4) and macro-micro (Arrow 1), micro-micro (Arrow 2), and micro-macro (Arrow 3).

\section{Insert Figure 1 here}


The diagram in the figure also makes a distinction between what is to be explained (i.e. the explanandum) and its explanation (the explanans). Usually, the aim is to explain either a macrolevel phenomenon (located in the upper right hand corner of Figure 1), such as a firm-level outcome, or a correlation between macro phenomena (i.e. Arrow 4). In order to explain, the analyst makes use of theoretical mechanisms that are consistent with the arrows (Hedström \& Swedberg, 1996; Salmon, 1998; Machamer, Darden \& Craver, 2000). An explanation of a phenomenon placed in the upper-right hand corner of the figure takes place by making use of [Arrow 3] or [Arrow 2 and Arrow 3] or [Arrow 1 and Arrow 2 and Arrow 3]. In other words, the phenomenon is explained in terms of an aggregation (which may allow for emergence) of the actions of the actors (Arrow 3). These actions may in turn be explained as taken under the impact of the circumstances surrounding the individual (Arrow 2), which in turn may be explained as being influenced by macro-level phenomena (Arrow 1).

It may seem that the framework allows for explanation that takes place solely in terms of Arrow 4, that is, explanatory accounts that are wholly located on the macro level. However, there are no conceivable causal mechanisms in the social world that operate solely on the macro level. There are no macro-level entities on the social domain that somehow possess capacities or dispositions to act that make them capable of directly producing macro-level outcomes (Salmon, 1998), and there are no processes of interaction between macro entities that take place on this level. In short, there is no macro-level causal mechanism that can be theoretically represented in terms of Arrow $4 .^{3}$ Still, Arrow 4 may be taken as no more than a representation of a correlation

\footnotetext{
${ }^{3}$ Note that this point does not concern whether the explanandum can be placed on the macro level. Many (most) explananda in social science are placed on this level (Coleman, 1990: 2) — notably, most of the phenomena that the SHRM field seeks to explain.
} 
between macro variables in need of further explanation on the micro level. This is entirely unproblematic. Moreover, Arrow 4 may be used as convenient shorthand in the sense that we can make use of Arrow 4 explanations when we are convinced that they can be reduced to micromechanisms, but performing this reduction would not add anything in the explanatory context (cf. Stinchcombe, 1991). However, this is hardly the case of the many instances of Arrow 4 explanation that exist in management (cf. Abell et al., 2008), such as the arguments that routines are a direct cause of firm-level adaptation (Nelson \& Winter, 1982), "combinative capabilities" cause firm-level innovativeness (Kogut \& Zander, 1992), and different "absorptive capacities" cause differences in how well firms learn from partner firms in inter-organizational relations (Lane \& Lubatkin, 1998). Most of the SHRM field essentially also reasons in a similar aggregative way; for example, HRM architectures may impact human capital pools, which has implications for firm performance. In all these cases, it is quite arguable that insight and understanding will be furthered by exploring micro-mechanisms (cf. Felin \& Hesterly, 2007).

\section{The Need for Micro-foundations}

We take the position that the explanation of firm-level (macro) phenomena in SHRM must ultimately be grounded in explanatory mechanisms that involve individual action and interaction (cf. Elster, 1989; Coleman, 1990). We also assume that the ultimate aim of scientific endeavor in the field of SHRM should be to identify and theorize the causal mechanisms - the "cogs and wheels" (Elster, 1989: 3) - that produce the observed associations between events. In this view, explanatory black boxes must be avoided (Boudon, 1998). Admittedly, black boxes may sometimes be justified in terms of explanatory parsimony (Hedström \& Swedberg, 1998: 12; see also Coleman, 1990: 16). Because HRM scholars may not always want to make explicit reference to complicated webs of interaction among employees, they often prefer to make use of 
explanatory shorthand in the form of collective concepts. This is completely legitimate. However, explanation in SHRM should nevertheless have a micro foundation.

First, a problem with macro-level explanation (i.e., Arrow 4) is that there are likely to be many alternative lower-level explanations of macro-level behavior which cannot be rejected with macro-analysis alone. Even if a large sample can be constructed on the basis of macro units of analysis, a problem of alternative explanations may persist. Thus, recent contributions to the SHRM field seek to explain differential firm performance in heterogeneity of practices and architectures (Kang et al., 2007). However, heterogeneity may be located at the individual level, notably when individuals self-select into particular firms (Felin \& Hesterly, 2007). Second, an argument for the importance of understanding micro-foundations lies in the fundamental mandate of SHRM: to assist strategy implementation and enable managers to gain and sustain competitive advantage (Huselid, Jackson \& Schuler, 1997; Becker \& Huselid, 2006). To achieve this, managerial intervention is required, which inevitably has to take place with an eye to the micro level. A third reason is that explanations that involve the micro level have the properties of being more stable, fundamental, and general than macro level explanations. As Coleman (1990: 3) argues:

An explanation based on internal analysis [i.e., micro-foundations] of system [organization] behaviour in terms of action and orientations of lower-level units is likely to be more stable and general than an explanation which remains at the system level. Since the system's behaviour is in fact resultant of the actions of its component parts, knowledge of how the actions of these parts combine to produce systematic behaviour can be expected to give greater predictability than statistical relations of surface characteristics of the system. 


\section{An Under-determined Model}

The above call for micro-foundations in general and in the SHRM field in particular is perhaps not a very controversial one. Few would disagree that additional insight into micro variables and mechanisms is useful for research as well as for managerial practice. Where dispute may arise concerns what exactly one should mean by "micro-foundations," that is, what concrete content such foundations should be given.

To see this, note that the arrows in Figure 1 are — from a theoretical perspective — "empty boxes" that can be filled with different kinds of theoretical mechanisms, quite dependent on the discretion of the researcher. Thus, Arrow 1 simply says that there are some mechanisms that mediate between macro variables and the conditions of individual actions. The model is silent about the nature of these mechanisms or which mechanisms may be relevant. In fact, there are many candidate mechanisms here. Continue with Arrow 1 as the example. One mechanism that is consistent with Arrow 1 is that individuals emulate roles that are widespread in society. Or, by assuming a job they also adopt a set of role characteristics. Another example of a mechanism that is consistent with Arrow 1 is that reward systems defined on the organizational level influence the conditions of individual actions by influencing the tradeoffs individuals face in their work/leisure choices. More generally, Arrows 1 and 2 are consistent with a broad set of models of individual behavior. These models may range from the economist's utility maximizing model to routine- or norm-based models; in other words, the model implies virtually nothing concerning how individual beliefs, rationality, motivation, etc. are actually modeled. Similarly, Arrow 3 is consistent with many different ways of aggregating individual actions, for example, allowing for synergies (or the opposite) between actions. 
Finally, note that the "emptiness" also relates to the variables (the nodes) in the figure. For example, the upper-left hand corner of the bathtub can contain formal as well as informal "social facts." Thus, it may refer to formal administrative apparatus in a firm as a well as to informal aspects of the organization.

In essence, all that the bathtub model in Figure 1 implies is the modest demand that an account must be provided of the mechanisms that bring us from macro to micro and back to macro, and that this account logically must follow the numbering of the arrows (i.e., 1, 2 and 3). Still, this is sufficient to structure a discussion of key research challenges of the SHRM field. Specifically, we use these arguments to construct Figure 2, which shows our overall logic as applied to the SHRM field. Note that the model in Figure 1 only portrays two levels of analysis (macro and micro). However, it is possible to place "bathtubs" on top of each other, so that more than two levels of analysis are shown. For example, if we place one bathtub on top of another one, we arrive at three levels of analysis, that is, a micro, a meso and a macro level. This is what is done in Figure 2, adding a level that consists of strategic and organizational antecedents (node A), and overall firm performance (e.g., growth, financial performance) (node F), and the corresponding arrows (1 and 6).

\section{Insert Figure 2 here}

Armed with this model, we can now use it to diagnose in a more precise manner some of the key issues that SHRM research needs to take into account. Thus, in the following we explicate the desiderata for research implied by Figure 2 by examining each one of the nodes [A, F], as well 
as the causal arrows $[1,5]$. We leave out a potentially important set of issues for SHRM research, namely whether there are global best practices in SHRM or whether the effectiveness and adoption of SHRM practices are constrained by country culture. Incorporating this would require one more level of analysis, further complicating an already complicated discussion.

\section{IMPLICATIONS FOR RESEARCH IN STRATEGIC HRM}

\section{From A to B / Arrow 1: What is the Role of Strategy and Organizational Antecedents?}

Recognition of the strategy (formulation and implementation)-HRM link has been emerging and is so central to the SHRM field that it may be seen as a defining feature. Yet, the majority of the studies reviewed in Table 1 do not explicitly approach the role of strategy in discussing the link between HRM and knowledge performance. This may be considered a serious limitation, since the choice of HRM is an important aspect of the implementation of knowledgebased strategies. For example, to succeed, corporate strategies involving changing the sourcing of inputs for innovation from a closed to an open model (Chesbrough, 2003) may need to be underpinned by changes in HRM practices. A more open innovation model is thus likely to require more emphasis on delegation and local initiative, communication and knowledge sharing, and possibly rewards for knowledge sharing (Foss et al., 2007).

A recent paper by Becker and Huselid (2006) suggests that future research on SHRM should shift its focus to strategy implementation. Specifically, they suggest considering "a new set of intermediate outcomes and a new locus of fit for the HR architecture" (Becker \& Huselid, 2006: 901). According to Becker and Huselid (2006), the link between strategy and firm performance is mediated by "an interrelated business process." Becker and Huselid (2006) used 
the definition by Ray, Barney and Muhanna (2004), according to whom a business process is the way in which the competitive potential of a firm's resources and capabilities are realised. Such a process has a significant firm-specific dimension and results in "strategic implementation effectiveness". Because of its firm-specificity — which implies both effectiveness and difficulty of imitation - the relevant process may be a cause of sustained competitive advantage. Such processes may be manifest in a HR architecture (core and differentiated) which, when implemented, aims at changing employees' behavior and in turn impact "strategic implementation effectiveness" (see Figure 1 in Becker \& Huselid, 2006).

Research on HRM and knowledge performance can benefit from heeding the Becker and Huselid idea. As a central "strategic business process" we suggest considering knowledge governance (Grandori, 1997, 2001; Peltokorpi \& Tsuyuki, 2006; Foss, 2007). Thinking on knowledge governance starts from the hypothesis that to realize the competitive potential of knowledge as a strategic resource, intra-organizational knowledge processes should be influenced and directed through the deployment of governance mechanisms, in particular the formal aspects of organization that can be manipulated by management, such as organization structure, information systems, standard operating procedures, accounting systems and other coordination mechanisms. Knowledge governance scholars assert that HRM practices are critical antecedents of knowledge processes (Grandori, 1997, 2001; Foss, 2007). By aligning this focus with the Becker and Huselid argument described above, a link between corporate strategy and knowledge performance emerges: a set of corporate strategies will be implemented via the deployment of various governance mechanisms that influence and direct intra-organizational knowledge processes (knowledge governance). The implementation will be manifested in both core and differentiated HR architecture (see Figure 1 in Becker \& Huselid, 2006). While the core 
HR architecture consists of best practices, the implementation of which "has equal value in all strategic business processes", the differentiated HR architecture is "structured to provide the unique human requirements of a specific business process", in our case knowledge governance (Becker \& Huselid, 2006: 906). The focus of differentiated HR architecture could be on the value and uniqueness of employees' skills (Lepak \& Snell, 1999, 2002), the job on which skills are used (Becker \& Huselid, 2006), outcomes of knowledge processes (Kang et al., 2007) or perhaps specific attributes of employees' behaviour (e.g. intrinsic motivation). Because the emphasis on strategy implementation and the need for differentiation is now more or less shared by SHRM researchers, we need empirical studies shedding light on the "the 'black box' between the HR architecture and firm performance" (Becker \& Huselid, 2006: 922).

Implication for SHRM research 1: Emphasizing strategy implementation in SHRM theory implies a mediating role of knowledge governance and a new locus of fit for the core and differentiated HR architecture. Research should explore the nature of this locus of fit.

\section{From B to C / Arrow 2. Which HRM Practices Matter? And How Are They Combined?}

The configurations of HRM practices which management has chosen to employ for their core employees are designed at the strategic level of the organization, and have been the focus of the majority of HRM research. Wright and Nishii (2006) refer to them as intended HRM practices (i.e., those that are "tied directly to the business strategy", cf. Arrow 1) and distinguish them from actual (those that "are actually implemented") and perceived ("perceived and interpreted subjectively by each employee") HRM practices. The distinction between what is intended (by management), what is perceived (by employees) is captured by Arrow 2.

The differences between intended and actual HRM practices are caused by a number of various organizational antecedents which would cause variations in the implementation of HRM 
practices across organizational units. There are also variations in individuals' reactions to the actual/implemented HRM practices, which may explain differences in perceived HRM practices. However, to date, there is no solid empirical evidence supporting the differences between intended, actual and perceived HRM practices (the studies reviewed in Table 1 are no exception). This is arguably related to the absence of multi-level theories and multi-level research in SHRM (Bowen \& Ostroff, 2004; Gerhart, 2005; Wright \& Nishii, 2006), as well as the failure of HRM researchers to collect multi-source individual level data, which would allow controlling for differences in reactions caused by individual heterogeneity. Overall, as Becker and Huselid argue, to advance, HRM scholars need to be pushed out of their "natural comfort zone", which assumes an unproblematic aggregation of individuals, the existence of an "average individual," and no differences in individual perceptions of, and reactions to, external stimuli (intended and actual HRM practices) (2006: 900).

We argue that individual-level differences likely mediate, and potentially strongly so, the relation between HRM and knowledge performance (Felin \& Hesterly, 2007). In this regard, various literatures point to the possibility of expanding the framework linking HRM practices and knowledge performance by introducing mediating variables in the form of individual-level variables such as ability, motivation and opportunity. Those variables are "the very outcomes that seem to have originally guided the construction of HR practice items" (Gerhart, 2005: 183) and individual-level variables explaining organizational-level knowledge processes (Argote, McEvily \& Reagans, 2003). Including those variables allows the researchers to theoretically identify individual as well as bundles of HRM practices, the implementation of which would increase knowledge-related behavior of individuals. 
As suggested by Table 1, there are two main directions along which empirical work on the link between HRM and individual level mediating variables has developed. One stream deals with the effect of the individual HRM practices, while the other one explores the complementarity effect of "bundles" of HRM practices on the employees' ability, motivation and opportunity.

Individual HRM practices. The focus of the empirical research has been divergent, and it is clear that rewards and training have attracted disproportionate attention. To be sure, these are important HRM practices, but it is hard to argue on a priori grounds that the positive impact of rewards and training on knowledge performance should be higher than the impact of, for example, job design variables. In fact, Bock et al. (2005) indicate that somewhat contrary to commonly accepted practices associated with knowledge management initiatives, extrinsic rewards may hinder the development of favorable attitudes toward knowledge sharing. Similar findings were obtained by Lopez et al. (2006), who evaluated the impact of a series of HRM practices (including compensation) on organizational learning (internal and external knowledge acquisition, distribution, interpretation, and retention in organizational memory). They found that practices such as the use of selective hiring, the extent of training and active participation of the employees in decision making were conducive to organizational learning, while group performance-based compensation was not found to be significant for organizational learning. ${ }^{4}$

A wider range of HRM practices was analyzed in Minbaeva et al. (2003). In particular, they found that the employment of competence-based performance appraisal and training affects

\footnotetext{
${ }^{4}$ Regarding training, Beugelsdijk (2008) found that not all types of training promote innovativeness: While training that focuses on research-related technical skills positively impacts innovation, management training has a negative effect.
} 
employees' ability to absorb knowledge, while merit-based promotion, performance-based compensation and internal communication affect their motivation to do so. Both ability and motivation need to be present in order to optimally facilitate the absorption of knowledge, which in turn resulted in increased intra-organizational knowledge transfer. Problematically, the data on employees' ability and motivation was limited due to the use of only one respondent per organizational unit. Furthermore, Minbaeva et al. did not examine other factors that may affect intra-organizational knowledge transfer, such as the relationship between the parties involved and/or the sender's characteristics. ${ }^{5}$ Finally, while all HRM practices included in the analysis can be expected on a priori grounds to somehow impact knowledge performance, the authors did not make any attempts to gauge their relative impact. Some practices may matter considerably, while other ones may only matter marginally. Our a priori conceptions may lead us astray, as indicated by the above two examples concerning rewards and training.

Implication for SHRM research 2: Research should examine the relative contribution of alternative HRM practices to knowledge performance (as mediated by such individual-level variables as ability, motivation and opportunity).

Bundles of HRM practices. A number of SHRM researchers have argued that complementarities or synergies are likely to exist among individual HRM practices (see, for example, Arthur, 1994; MacDuffie, 1995; Huselid, 1995; Youndt, Snell, Dean \& Lepak, 1996; Delaney \& Huselid, 1996; Delery \& Doty, 1996; Ichniowski, Shaw \& Prennushi, 1997; Huselid et al., 1997). These studies indicate that when HRM practices are applied as coherent systems, they have greater effects on organizational outcomes (e.g. firm-level productivity) than the sum

${ }^{5}$ These were later addressed in Minbaeva and Michailova (2004) and Minbaeva (2007). 
of the individual effects from each practice alone. The reason is ascribed to some synergistic effect stemming from the systemicness of the relevant HRM practices.

Along this logic, the most popular way to theorize HRM practices has been a "best practices"/"high performance HRM practices approach. The idea in general seems attractive: Regardless of location, industry, markets, etc., “... the effects of high performance management practices are real, economically significant, and general - and thus should be adopted by your organizations" (Pfeffer, 1994: 34). The findings of empirical studies on this subject are similar: The more that high performance HRM practices are used, the stronger the performance (however measured). Yet, this line of research has received as much critique as support. Skeptics put forward reasonable arguments that there is a danger of adopting overly simplistic solutions that are based on the results of statistical analysis rather than serious conceptual work (see Guest, Michie, Conway \& Sheehan [2003] for a review). Becker and Huselid (2006) themselves, while standing by the idea that "... many firms will benefit from the adoption of high-performance work system 'best practices"” (p. 905), call for "a much greater focus on differentiation in the HR architecture, both between firms and within firms" (p. 916).

Taking this call further, we argue that traditional prescriptions of high performance HRM practices (or "best practices") do not fit the emerging knowledge-related goals of organizations. As Guest (1997) argues, HRM practices should be designed to lead to certain outcomes. When outcomes are changing, the chosen HRM practices should be re-examined. Hence, one should not simply accept findings from the previous literature on HRM and (business) performance and substitute performance variables with something "knowledge related." In fact, the very idea of "best practices" may be difficult to square with current thinking in strategic management, notably the key resource-based idea that success is dependent on firm-specific, idiosyncratic factors, 
whereas "best practices" can be copied by the competition, and hence will only lead to average performance (Barney, 1991). Sustained competitive advantage is rather related to "very distinct management practices" (Becker, Huselid, Pickus \& Spratt, 1997).

Another problem associated with the adoption of the high performance HRM practices approach is that, although repeated efforts have been made, scholars are not in agreement concerning which HRM practices need to be bundled to constitute a set of "high performance HRM practices." In other words, such practices vary across both the studies of HRM performance and the (limited) studies on HRM and knowledge performance. To exemplify the latter, consider two representative studies. Laursen and Foss (2003) investigated the link between HRM practices and innovation performance, and argued that HRM practices are "most conducive to innovation performance when adopted, not in isolation, but as a system of mutually reinforcing practices" (p.249). Indeed, they argue that "while the adoption of individual HRM practices may be expected to influence innovation performance positively, the adoption of a package of complementary HRM practices could be expected to affect innovation performance much more strongly" (Laursen \& Foss, 2003: 257). However, applying principal component analysis, they actually identified two distinct HRM systems, which may positively impact innovation performance. The first one consists of complementary HRM practices, which matter for the ability to innovate, namely interdisciplinary workgroups, quality circles, systems for collection of employees' proposals, planned job rotation, delegation of responsibility, integration of functions, and performance-related pay. The second system is dominated by firm-internal and firm-external training. Moreover, Laursen and Foss (2003) did not provide an explanation in terms of individuals' motivation, ability and opportunity of why exactly HRM practices may be 
synergistic with respect to their impact on innovation performance. Their argument lacks critical micro-foundations.

Another study by Collins and Smith (2006) considered how commitment-based HR practices affect the organizational social climate conditions that facilitate knowledge exchanges and combination, and resultant firm performance. They used 16 items representing three dimensions of HRM: selection, incentive, and training and development policies. The 16 items were factor-analyzed and loaded on a single factor with an eigenvalue of 9.51 (Cronbach alpha 0.87). That allowed the authors to use a single commitment-based HR factor which was found to be indirectly related to firm performance through their effects on organizational social climate and knowledge exchange and combination.

In the first study, a possible problem is one of equifinality: Very different HRM systems can produce the same outcome. In the second study, the problem appears to be one of an overly expansive set of HRM practices. The two studies are both driven more by empirics than by conceptual and theoretical reasoning. As Guest (1997) noted, "while [such] studies represent encouraging signs of progress, statistical sophistication appears to have been emphasized at the expense of theoretical rigor" (p. 263).

Implication for SHRM research 3: Research should theoretically identify bundles of HRM practices that matter for knowledge performance. The theoretical rationale must provide an account based on individuals' ability, motivation and opportunity of why one may expect certain bundles of practices to be synergistic with respect to knowledge performance and not others.

\section{From C to D / Arrow 3: Individual Level Processes and Variation}


According to the original formulation of the "Coleman bathtub" (Coleman, 1990), nodes C and D represent the "conditions of individual actions" and "individual actions" respectively. Above we have suggested considering ability, motivation and opportunity as "conditions of individual actions" which when influenced/governed via the employment of HRM practices explain variations in individual knowledge-related behavior (i.e., node D). ${ }^{6}$ Considering ability, motivation and opportunity as "conditions" may also be clarified by drawing on studies on information processing of external information. In particular, the Motivation-Opportunity-Ability (MOA) framework extensively developed by MacInnis and Jaworski (1989) and MacInnis et al. (1991) seems promising in this regard. In the original conceptualization, the MOA framework was used to explain how consumers process external information, linking individual behavior with the processing of that information.

The MOA approach seems particularly appropriate for examining the individual-level antecedents of knowledge performance as it moves away from the structure/content assumption characterizing previous research and adopts a more process-driven view (Lane, Koka \& Pathal, 2006). Cohen and Levinthal (1990) point to ability as a key part of the firm's ability to absorb new knowledge. Indeed, individuals' ability may represent the "prior related knowledge" (Kim, 2001) that is required for knowledge absorption. Experience in one learning task may influence and improve performance in subsequent ones. Hence, "the prior possession of relevant knowledge and skill" is key for knowledge absorption because it leads to increased creativity and associations between previously unconnected information (Cohen \& Levinthal, 1990).

\footnotetext{
${ }^{6}$ The notions of ability, motivation and opportunity have been extensively used in HRM research as mediating variables in explaining the link between HRM and performance (e.g. Huselid 1995; Delaney and Huselid, 1996; Appelbaum et al., 2000).
} 
The critical role of motivation has also been observed in the literature concerning knowledge processes, in which individual motivation is posited to influence knowledge performance positively (Argote \& Ingram, 2000; Argote et al., 2003; Quigley, Tesluk, Locke \& Bartol, 2007; Szulanski, 1996, 2000). Further, the literature recommends considering at least two types of motivation, namely extrinsic and intrinsic (Osterloh, Frost \& Frey, 2002: 67), as they have differential impacts on knowledge processes. There is evidence in the literature that extrinsic motivation may not be quite as effective a determinant of individual knowledge-related behavior or learning as intrinsic motivation. For example, intrinsically motivated employees may exhibit higher levels of learning than extrinsically motivated employees (Deci \& Flaste, 1995), because people are typically at their most creative when their motivation stems from within (Amabile, 1997). As Osterloh and Frey (2000) suggest, when tacit knowledge is involved and multiple-task problems are combined with the problem of "free riding" in teams, intrinsic motivation enables knowledge transfer under conditions in which extrinsic motivation fails.

Argote et al. (2003) were among the first to discuss opportunity (along with ability and motivation) as an important variable explaining organizational-level knowledge processes. They argue that the effect of ability and motivation on the acquisition and use of knowledge by an individual may be influenced by the existence of opportunity: "ability and extra effort are even more valuable when coupled with opportunity ... to create, retain and transfer knowledge" (Argote et al., 2003: 575). At the interpersonal level, Uzzi (1997) and Uzzi and Lancaster (2003) observed that embedded ties characterized by close interaction are associated with a higher level of knowledge sharing than more arms-length ones. Hence, organizations try to "reduce the amount of distance" (Argote et al., 2003: 575) by building communication bridges, offering possibilities for dialogue across the organizational hierarchy, improving conditions for team 
learning, and creating the systems to capture and share knowledge within the organization (Levitt \& March, 1988; Senge, 1990; Argyris \& Schon, 1996). Yet, it is not just the pure existence of various opportunities to interact, but rather the use of them that is important for knowledge acquisition and use (Cabrera et al., 2006).

Implication for SHRM research 4: Research should clarify how differences in individual abilities, motivation, and use of interaction opportunities provided by the organization explain part of the variation found in individual knowledge-related behavior (individuallelel knowledge creation, acquisition, use, integration, and transfer).

\section{From D to E / Arrow 4: From the Individual to the Organizational Level}

Arrow 4 represents the aggregation of the individual knowledge-related actions (i.e., individual employees' creation, acquisition, use, integration, and transfer) to the organiztional level outcomes, namely knowledge performance. The movement from micro to macro involves a potentially strong interdependence between an action of an individual and that of others in the same context, particularly when actions are explicitly "strategic" in the sense that actors take into account the actions of other actors (Abell, 2003). Organizations are systems of interdependent actions, which lead to familiar problems of free-riding, moral hazard, opportunism and the like (e.g., Coleman, 1966: 50), as well as problems of coordinating actions (sans incentive conflicts). While acknowledging that it may be hard to fine tune individual behaviors so that they lead to the positive aggregate result, we nevertheless follow the original Coleman logic, which argues that the aggregate-level outcomes are usually more that a mere sum of individual-level outcomes. To reflect this, the model depicted in Figure 1 is presented in the form of a trapezium (as in Coleman, 1990). 
Explaining such interdependencies has proved to be a "main intellectual hurdle both for empirical research and for theory that treats macro-level relation via methodological individualism" (Coleman, 1986: 1323). Studies on SHRM and knowledge are no exception. Among the reviewed studies, none has explicitly dealt with this, neither conceptually nor empirically.

One potentially interesting approach that future SHRM researchers might consider taking to tackle the puzzling micro to macro aggregation is offered by Rico, Sánchez-Manzanares, Gil \& Gibson (2008). The authors considered team level knowledge structures as underlying mechanisms enabling implicit coordination behaviors of individual members that in turn form an aggregate phenomenon at the team level (Kozlowski \& Klein, 2000). Team level knowledge structures — or, as Rico et al. label them, "team situation models" — are the "mental representation associated with a dynamic understanding of the current situation (i.e. environment, task, team) that is developed by team members moment by moment (e.g. understanding by a consulting team of the particular financial problems facing a client company)". When team level knowledge structures are shared and accurate, the overall team performance will be more than a sum of individual outcomes. Rico et al. use the example of a football team, where the team develops an understanding of the strategy used by the opposite team during a match without discussion and explicit guidelines. If this understanding is shared by all members of the focal team and it is accurate, the team would be able to develop a counter attack strategy to overcome the opponent. 'Sharedness' and 'accuracy' are dependent upon four team composition factors team longevity, knowledge similarity (non-diversity), intra-group trust and group efficacy.

Sharedness and accuracy of team-level knowledge structures are necessary but not sufficient conditions for the positive aggregate outcomes. Rico et al. (2008) argue that implicit 
coordination processes will partially mediate the relationship between the sharedness and accuracy of the team-level knowledge structures and aggregate team performance. Implicit coordination has two basic components: (1) anticipation, which is revealed in the expectations and predictions team members formulate regarding the demands of the task and the actions and needs of others, without being directly notified of these actions or needs; (2) dynamic adjustment, which appears in those actions taken by team members on an ongoing basis in order to mutually adapt their behavior (Rico et al. 2008: 165).

For management, governing of the implicit coordination is a tricky task as implicit coordination components — anticipation and dynamic adjustment — are deeply rooted in individual psychological reciprocal reactions. However, there are other features of the task and the context within which work teams operate that might be more interesting for SHRM researchers since they represent various mechanisms that could be employed by management to ensure the positive aggregation from micro to macro. Specifically, Rico et al. (2008) examined the potential moderating roles of (1) task routineness: the extent to which highly routine tasks are well-defined, highly structured and encompassing predictable situations that can be resolved using standardized procedures; (2) task interdependence: the interconnections among the tasks of team members; and (3) virtuality in the relationship: the extent to which team members rely on virtual tools to coordinate and execute team processes, the amount of information value provided by such tools, and the synchronicity of team members' interactions. These three features are the job characteristics of the team - the outcomes of the team-based job design.

Implication for HRM research 5: Research should examine how individual knowledgerelated behavior (i.e., individual employees' creation, acquisition, use, integration, and 
transfer) are aggregated to organizational level outcomes and specifically, how the process of aggregation is dependent upon the use of HRM practices (such as job design).

\section{From E to F / Arrow 5: From Knowledge Performance to Overall Organizational Performance}

The final arrow in Figure 2 represents the link between knowledge performance of the organization and its overall business performance in terms of achieved strategic objectives. Strictly speaking, this arrow is not the domain of SHRM research per se. Rather, it belongs to strategic management, particularly to resource- and knowledge-based inquiries. However, an overall implication of this paper is that the link between how well an organization does in terms of its creation, use, etc. of knowledge and its overall performance has an important microdimension consisting of individual knowledge-related behaviors and how these are influenced by HRM practices. This reinforces the argument that the real locus of knowledge-related competitive advantage may lie at the level of individuals and individual interaction rather than at the organizational level per se, or, as a minimum, that the explanation of such advantage is a complex interplay between individual- and organizational-level factors.

\section{CONCLUSION}

In this paper, we have developed a case for SHRM research to build explicit foundations for the HRM-knowledge-performance link that are rooted in the level of individuals and their interaction. The SHRM field has mainly operated in the aggregate mode, as witnessed by the recent concentration on aggregate variables such as "architectures" as key constructs, and how these influence organization-level outcome variables. In actual research practice, a consequence 
of conducting theorizing in an aggregate mode is that individual variation tends to be either disregarded in favor of a homogeneity assumption (Dansereau \& Yammarino, 2005; Felin \& Hesterly, 2007) or at least an assumption that individual variation does not change. This is exactly the case of the SHRM field: The focus on the organization or business unit as the relevant unit of analysis implies that individual-level variation or development is disregarded.

However, the broader HRM field is perfectly suited to supply micro-foundations because of its inherent interest in the individual employee. HRM practices are designed and applied at the organizational level, but typically "operate through individual level employee reactions" (Gerhart, 2005: 177). Hence, HRM has the potential to constitute parts of the much-needed micro-foundations for work on the HRM-knowledge performance link (Felin \& Hesterly, 2007). The potential is, however, not being realized at the moment. We have argued that it is due to the lack of multi-level reasoning and failure to bring in the missing micro-foundations in the SHRM research.

To assist in realization of this potential, we provided a diagnostic tool to help us identify in a more precise manner some of the key issues that future SHRM research must deal with. The model in Figure 2 obviously simplifies what are complicated causal mechanisms, relations of embeddedness, and much else in the form of "arrows" linking various "nodes" located at multiple levels of analysis. However, it remains a useful first simplification and one that we applied for the purpose of mapping existing research and identifying implications for future SHRM research. This is not to say that "nodes" and "arrows" have not been attended before in theoretical and empirical studies. For example, Arrow 3, connecting nodes C and D, is relatively well documented in knowledge-based literature, both theoretically and empirically (see Argote et al., 2003 for a review). In HRM studies, Arrow 2 is also attended to; however, the existing 
empirical studies disregarded multi-level reasoning of the relations between organizational-level HRM practices and individual-level ability, motivation and opportunity. Therefore, in the case of Arrow 2 (as well as all other arrows) we tried to explicate the desiderata for future theoretical inquiries and empirical investigations.

As Whetten argues, "one way to demonstrate the value of a proposed change ... is to identify how this change affects the accepted relationships between the variables" (1998: 492). Which relationships is our model changing? Correlations between macro variables, represented in our model by dotted horizontal lines, would probably remain. Yet, by specifying the research logic underlying our model we would assist future research to explain why such correlations exist. That, according to Whetten, is "probably the most fruitful, but also the most difficult avenue of theory development" (1998: 493).

We should also point out the potential limitations of our model. First, many causal relations - "arrows" - were simplified. For example, Arrow 2 could be further specified by distinguishing between intended, actual and perceived HR practices (Wright \& Nishii, 2005). We intentionally decided not to do that to reduce complexity and concentrate on presenting the underlying logic. Further, more attention needs to be devoted to understanding interaction effects between governance mechanisms (HRM practices) in influencing knowledge performance. Proper standards for testing for complementarity effects are only emerging (Athey and Stern, 2003) so the corresponding empirical work needs to be done.

Although many testable propositions could be derived from our model, we limited ourselves to formulating research implications only. Since the model consists of "arrows" connecting "boxes", all relationships in the model could be tested. Further, each "arrow" can be filled with different kinds of relations. Consider Arrow 3 as an example. The simplified link in 
the model argues for the direct effect of ability, motivation and opportunity on individual knowledge-related behaviors. However, studies on information processing (e.g. MacInnis \& Jaworski, 1989) claim that ability, motivation and opportunity affect individual behavior at different points: while ability and motivation are endogenous to individuals, opportunities are provided from outside. Moreover, one may assume that the extent to which individuals use the interaction opportunities provided by the organization may be dependent upon their ability to recognize and motivation to use the provided opportunities. Finally, a more nuanced approach to motivation would allow distinguishing between extrinsic and intrinsic motivation. Intrinsically motivated individuals may use interaction opportunities more as they believe that such behavior promotes interpersonal trust, and sharing of meanings and understanding.

These limitations aside, we believe the research is timely. The topic is of contemporary interest to scholars in SHRM. It integrates perspectives from various research fields (SHRM, KBV, KGA, team learning). It accommodates different levels of analysis: strategic, organizational/group, and individual. We are not looking for confirmation of the whole model; this is admittedly challenging because multi-level issues complicate such empirical work (cf. Klein et al, 1994, Dansereau, 1997). But we urge future research to consider the underlying logic and attend under-researched issues which we identified in the form of logically deduced implications for research. 


\section{REFERENCES}

Amabile, T. 1997. Motivating creativity in organizations: on doing what you love and loving what you do. California Management Review, 40(1): 39-57.

Abell, P. 2003. On the prospects for a unified social science: economics and sociology. SocioEconomic Review, 1: 1-21.

Abell, P., Felin, T \& Foss, N. 2008. Building microfoundations for the routines, capabilities, and performance links. Managerial and Decision Economics, forthcoming.

Argote, L., McEvily, B., \& Reagans, R. 2003. Managing knowledge in organizations: An integrative framework and review of emerging themes. Management Science, 49(4): 571582.

Argote, L., \& Ingram, P. 2000. Knowledge transfer: A basis for competitive advantage in firms. Organizational Behavior and Human Decision Processes, 82(1): 150-169.

Argyris, C. \& Schön, D. 1996. Organizational learning II: Theory, method and practice. Reading: Addison Wesley.

Arthur, J. 1994. Effects of human resource systems on manufacturing performance and turnover. Academy of Management Journal, 37: 670-687.

Arthur, J. \& Kim, D. O. 2005. Gainsharing and knowledge sharing: The effects of labourmanagement co-operation. The International Journal of Human Resource Management, 16(9), 1564-1582.

Barney, J. B. 1991. Firm resources and sustained competitive advantage. Journal of Management, Vol. 17(1): 99-120.

Barney, J. B., Wright, M., \& Ketchen, D. J. 1991. The resource-based view of the firm: Ten years after 1991. Journal of Management, 27: 625-641.

Becker, B., Huselid, M., Pickus, P., \& Spratt, M. 1997. HR as a source of shareholder value: Research and recommendations. Human Resource Management, 36(1): 39-47.

Becker, B. \& Huselid, M. 2006. Strategic Human Resource Management: Where do we go from here? Journal of Management, 32(6): 898-925

Beugelsdijk, S. 2008. Strategic Human Resource Practices and Product Innovation. Organization Studies, 29(6): 821-847.

Björkman, I., Barner-Rasmussen, W., \& Li, L. 2004. Managing knowledge transfer in MNCs: the impact of headquarters control mechanisms. Journal of International Business Studies, 35: 443- 455.

Bock, G., R. Zmud, Y. Kim, J. Lee. 2005. Behavioral intention formation in knowledge sharing: Examining the roles of extrinsic motivators, social-psychological forces, and organizational climate. MIS Quarterly, 29(1): 87-111.

Boudon, R. 1998. Limitations of rational choice theory. American Journal of Sociology, 104: 817-826.

Bowen, D. E. \& Ostroff, C. 2004. Understanding HRM-firm performance linkages: The role of the "strength" of the HRM system. Academy of Management Review, 29(2): 203-221. 
Cabrera, A., Collins, W.C., \& Salgado, J.F. 2006. Determinants of organizational engagement in knowledge sharing. International Journal of Human Resource Management, 17: 245264.

Caligiuri, P. 1999. The ranking of scholarly journals in international human resource management. The International Journal of Human Resource Management, 10(3): 515519.

Chesbrough, H. 2003. Open innovation: The new imperative for creating and profiting from technology. Boston: Harvard Business School Press.

Cohen, W.M. \& Levinthal, D.A. 1990. Absorptive capacity: A new perspective on learning and innovation. Administrative Science Quarterly, 35: 128-152.

Coleman, J. S. 1966. Foundations for a theory of collective decisions. AmericanJournal of Sociology, 71: 615-627.

Coleman, J. S. 1986. Social theory, social research, and a theory of action. American Journal of Sociology, 91(5): 1309-1335.

Coleman, J. S. 1990. Foundations of social theory. Cambridge/London: The Belknap Press of Harvard University Press.

Collins, C. J. \& Smith, K. G. 2006. Knowledge exchange and combination: The role of human resource practices in the performance of high technology firms. Academy of Management Journal, 49: 544-560.

Currie, G. \& Kerrin, M. 2003. Human resource management and knowledge management: Enhancing knowledge sharing in a pharmaceutical company. International Journal of Human Resource Management, 14(6): 1027-1045.

Dansereau, F. \& Yammarino, F.J. 2005. Multi-level issues in strategy and method. Amsterdam: JAI Press.

Deci, E. \& Flaste, R. 1995. Why we do what we do: The dynamics of personal autonomy. New York: Putnam's Sons.

Delaney, J., \& Huselid, M. 1996. The impact of human resource management practices on perceptions of organizational performance. Academy of Management Journal, 39(4): 949969.

Delery, J., \& Doty, H. 1996. Modes of theorizing in strategic human resource management: Tests of universalistic, contingency, and configurational performance predictions. Academy of Management Journal, 39(4): 802-835.

Eisenhardt, K. M. 1989. Building theories from case study research. The Academy of Management Review, 14(4): 532-550.

Eisenhardt, K. M. \& Santos, F. M. 2003. Knowledge- based view: A new view of strategy. In A. Pettigrew, H. Thomas, \& Richard Whittington (Eds.), Handbook of Strategy and Management. London: Sage.

Elster, J. 1989. Nuts and bolts for the social sciences. Cambridge: Cambridge University Press.

Extejt, M., \& Smith, J. 1990. The behavioral sciences and management: An evaluation of relevant journals. Journal of Management, 16(3): 539-551. 
Felin, T. \& Foss, N. J. 2005. Strategic organization: A field in search of micro-foundations. Strategic Organization, 3: 441- 455.

Felin, T. \& Hesterly, W.S. 2007. The Knowledge-based view, heterogeneity, and the individual: Philosophical considerations on the locus of knowledge. Academy of Management Review, 32: 195-218.

Felin, T., Tomsik, J., \& Zenger, T. 2008. The knowledge economy: Emerging organizational forms, microfoundations and key human resource heuristics. Human Resource Management, forthcoming.

Ferner, A., Almond, P. \& Colling, T. 2005. Institutional theory and the cross-national transfer of employment policy: The case of "Workforce Diversity" in US multinational. Journal of International Business Studies, 36: 304-321.

Gerhart, B. 2005. Human resources and business performance: Findings, unanswered questions, and an alternative approach. Management Review, 16(2): 175-185.

Gittel, J. 2000. Organizing work to support relational co-ordination. International Journal of Human Resource Management, 22(3): 517-539.

Gómez, P. J., Lorente, J. J. C., \& Cabrera, R. V. 2004. Training practices and organisational learning capability: Relationship and implications. Journal of European Industrial Training, 28: 234-256.

Gomez-Mejia, L., \& Balkin, D. 1992. Determinants of faculty pay: An agency theory perspective. Academy of Management Journal, 35(5): 921-955.

Grandori, A. 1997. An organizational assessment of interfirm coordination modes. Organization Studies, 18(6): 897-925.

Grandori, A. 2001. Neither hierarchy nor identity: Knowledge governance mechanisms and the theory of the firm. Journal of Management and Governance, 5: 381-399.

Grandori, A., \& Kogut, B. 2002. Dialogue on organization and knowledge. Organization Science, 13: 224-232.

Grant, R. M. 1996. Towards a knowledge-based theory of the firm. Strategic Management Journal, 17: 109-122.

Guest, D. 1997. Human resource management and performance: A review and research agenda. International Journal of Human Resource Management, 8(3): 263-276.

Guest, D., Michie, J., Conway, N., \& Sheehan, M. 2003. Human resource management and corporate performance in the UK. British Journal of Industrial Relations, 41: 291-314.

Hatch, N., \& Dyer, J. 2004. Human capital and learning as a source of sustainable competitive advantage. Strategic Management Journal, 25: 1155-1178.

Hedström, P., \& Swedberg, R. 1996. Social mechanisms. Acta Sociologica, 39: 281-308.

Hocking, J., Brown, M., \& Harzing, A. -W. 2004. A knowledge transfer perspective of strategic assignment purposes and their path-dependent outcomes. International Journal of Human Resource Management, 15(3): 565-572.

Hoobler, J., \& Johnson, N. 2004. An analysis of current human resource management publications. Personnel Review, 33(6): 665-676. 
Huselid, M. 1995. The impact of human resource management practices on turnover, productivity, and corporate financial performance. Academy of Management Journal, 38(3): 635-672.

Huselid, M. Jackson, S., \& Schuler, R. 1997. Technical and strategic human resource management effectiveness as determinants of firm performance. Academy of Management Journal, 40(1): 171-188.

Ichniowski, C., Shaw, K., \& Prennushi, G. 1997. The effects of human resource management practices on productivity: A study of steel finishing lines. The American Economic Review, June: 291-313.

Jansen J. J. P, van den Bosch, F. A. J., \& Volberda, H. W. 2006. Managing potential and realized absorptive capacity: How do organizational antecedents matter? Academy of Management Journal, 48: 999-1015.

Jaw, B. S. \& Liu, W. 2003. Promoting organizational learning and self-renewal in Taiwanese companies: The role of HRM. Human Resources Management, 42(3): 223-41.

Jaw, B. S., Wang, C. Y. P. \& Chen, Y. H. 2006. Knowledge flows and performance of multinational subsidiaries: The perspective of human capital. International Journal of Human Resource Management, 17(2): 225-244.

Jerez-Gomez, P., Cespedes-Lorente, J., \& Valle-Cabrera, R. 2005. Organizational learning capability: A proposal of measurement. Journal of Business Research, 58(6): 715-725.

Johnson, J., \& Podsakoff, P. 1994. Journal influence in the field of management: An analysis using Salancik's index in a dependency network. Academy of Management Journal, 37(5): 1392-1407.

Kang, S. C., Morris, S. \& Snell, S.A. 2007. Relational archetypes, organizational learning, and value creation: Extending the human resource architecture. Academy of Management Review, 32: 236-256.

Kim, Linsu. 2001. Absorptive capacity, co-operation, and knowledge creation: Samsung's leapfrogging in semiconducters. In I. Nonaka \& T. Nishiguchi (Eds.), Knowledge Emergence- Social, Technical, and Evolutionary Dimensions of Knowledge Creation: 270-86. Oxford: Oxford University Press.

Kogut, B. \& Zander, U. 1992. Knowledge of the firm, combinative capabilities, and the replication of technology. Organization Science, 3: 383-397.

Kozlowski, S. W. J., \& Klein, K. J. 2000. A multilevel approach to theory and research in organizations. In S. W. J. Kozlowski \& K. J. Klein (Eds.), Multilevel theory, research, and methods in organizations: Foundations, extensions, and new directions: 3-90. San Francisco: Jossey-Bass.

Kuhn, T. 1970. The structure of scientific revolutions. Chicago: University of Chicago Press.

Lado, A., \& Wilson, M. 1994. Human resource systems and sustained competitive advantage: A competency-based perspective. Academy of Management Review, 19: 699-727.

Lane, P., \& Lubatkin, M. 1998. Relative absorptive capacity and interorganizational learning. Strategic Management Journal, 19(5): 461-477. 
Lane, P., Koka, B. \& Pathal, S. 2006. The reification of absorptive capacity: A critical review and rejuvenation of the construct. Academy of Management Review, 31(4): 833-863.

Laursen, K. \& Foss, N. J. 2003. New HRM practices, complementarities, and the impact on innovation performance. Cambridge Journal of Economics, 27: 243-263.

Lepak, D. \& Snell, S. 1999. The strategic management of human capital: Determinants and implications of different relationships. Academy of Management Review, 24(1):1-18.

Lepak, D., \& Snell, S. 2002. Examining the human resource architecture: The relationships among human capital, employment, and human resource configurations. Journal of Management, 28: 517-543.

Levitt, B. \& March, J. G. 1988. Organizational learning. American Review of Sociology, 14: 212-243.

López, S. P., Peón, J. M., \& Ordás, C. J. 2006. Human resource management as a determining factor in organizational learning. Management Learning, 37(2): 215-239.

Lyles, M. A. \& Salk, J. E. 1996. Knowledge acquisition from foreign parents in international joint ventures: An empirical examination in the Hungarian context. Journal of International Business Studies, 27(5): 877-903.

MacDuffie, J. 1995. Human resource bundles and manufacturing performance: Flexible production systems in the world auto industry. Industrial \& Labor Relations Review, 48(2): 197-221.

Machamer, P., L. Darden, \& Craver, C.F. 2000. Thinking about mechanisms. Philosophy of Science, 67: 1-25.

MacInnis, D. J. \& Jaworski, B. J. 1989. Information processing from advertisements: Toward an integrative framework. Journal of Marketing, 53 (4): 1-24.

MacInnis, D.J., Mooreman, C. \& Jaworski, B.J. 1991. Enhancing and measuring consumers' motivation, opportunity, and ability to process brand information from ads. Journal of Marketing, 55: 32-53.

Minbaeva, D. B. 2005. HRM practices and MNC knowledge transfer. Personnel Review, 34(1): 125-144.

Minbaeva, D. 2007. Knowledge transfer in multinational corporations. Management International Review, 47(4): 567-594.

Minbaeva, D. \& Michailova, S. 2004. Knowledge transfer and expatriation practices in MNCs: The role of disseminative capacity. Employee Relations, 26(6): 663-679.

Minbaeva D., Pedersen, T., Björkman, I., Fey, C., \& Park, H. J. 2003. MNC knowledge transfer, subsidiary absorptive capacity, and HRM. Journal of International Business Studies, 34: 586-599.

Nelson, R. R. \& Winter, S. G. 1982. An Evolutionary Theory of the Firm. Cambridge, MA: Harvard University Press.

Nickerson, J., \& Zenger, T. 2004. A Knowledge-based theory of the firm: The problem-solving perspective. Organization Science, 15(6): 617-632. 
Osterloh, M. \& Frey, B. 2000. Motivation, knowledge transfer and organizational form. Organization Science, 11: 538-550.

Osterloh, M., Frost, J., \& Frey, B. S. 2002. The dynamics of motivation in new organizational forms. International Journal of the Economics of Business, 9: 61-77.

Pak, Y. \& Pak, Y. 2004. A framework of knowledge transfer in cross-border joint ventures: An empirical test of the Korean context. Management International Review, 44(4): 417-434

Pearl, J. 2000. Causality: Models, Reasoning, and Inference. Cambridge: Cambridge University Press.

Peltokorpi, V. \& Tsuyuki, E. 2006. Knowledge governance in a Japanese project-based organization. Knowledge Management Research \& Practice, 4: 36-45.

Persson, M. 2006. Unpacking the Flow: Knowledge Transfers in MNCs. Doctoral Thesis, Uppsala University. No. 118.

Pfeffer, J. 1994. Competitive advantage through people: Unleashing the power of the work force. Boston: Harvard Business School Press.

Quigly, N. R., Tesluk, P. E., Locke, E. A., \& Bartol, K. M. 2007. A multilevel investigation of the motivational mechanisms underlying knowledge sharing and performance. Organizational Science, 18: 71-88.

Ray, G., Barney, J. B., \& Muhanna,W. A. 2004. Capabilities, business processes, and competitive advantage: choosing the dependent variable in empirical tests of the resourcebased view. Strategic Management Journal, 25: 23-37.

Rico, R., Sánchez-Manzanares, M., Gil, F. \& Gibson, C. 2008. Team implicit coordination processes: A team knowledge-based approach. Academy of Management Review, 33(1): 163-184.

Salmon, W. 1998. Causality and Explanation. New York: Oxford University Press.

Senge, P. 1990. The Fifth Discipline: the Art and Practice of the Learning Organization. New York: Doubleday.

Stinchcombe, A. L. 1991. The conditions of fruitfulness of theorizing about mechanisms in social science. Philosophy of the Social Sciences, 21: 367-388.

Swart, J. \& Kinnie, N. 2003. Sharing knowledge in knowledge-intensive firms. Human Resource Management Journal, 13(2): 60-75.

Szulanski, G. 1996. Exploring internal stickiness: Impediments to the transfer of best practice within the firm. Strategic Management Journal, 17(10): 27-43.

Szulanski, G. 2000. The process of knowledge transfer: A diachronic analysis of stickiness. Organizational Behavior and Human Decision Processes, 82: 9-27.

Tahai, A., \& Meyer, M. 1999. A revealed preference study of management journals' direct influences. Strategic Management Journal, 20: 279-296.

Teece, D.J. 2007. Explicating dynamic capabilities: The nature and microfoundations of (sustainable) enterprise performance. Strategic Management Journal, 28: 1319-1350. 
Uzzi, B. 1997. Social structure and competition in interfirm networks: the paradox of embeddedness. Administrative Science Quarterly, 42: 35-67.

Uzzi, B. \& Lancaster, R. 2003. Relational embeddedness and learning: the case of bank loan managers and their clients. Management Science, 49(4): 383-399.

Whetten, D. 1989. What constitutes a theoretical contribution? Academy of Management Journal, 14(4): 490-495.

Wright, P., \& Nishii, L. 2006. Strategic HRM and organizational behavior: Integrating multiple levels of analysis. Working Paper 06-05. CAHRS Working Paper Series, Cornell University, NY.

Wright, P., Dunford, B., \& Snell, S. 2001. Human resources and the resource based view of the firm. Journal of Management, 27: 701-721.

Wright, P., Gardner, T., Moynihan, L., \& Allen, M. 2005. The relationship between HR practices and firm performance: Examining causal order. Personnel Psychology, 58: 409-446.

Wright, P. \& Haggerty, J. 2005. Missing variables in theories of strategic human resource management: Time, case and individuals. Management Review, 16(2): 164-173.

Youndt, M., Snell, S., Dean, J., \& Lepak, D. 1996. Human resource management, manufacturing strategy, and firm performance. Academy of Management Journal, 39(4): 836-866.

Zarraga, C. \& Bonache, J. 2003. Assessing the team environment for knowledge sharing: An empirical analysis. International Journal of Human Resource Management, 14(7): 1227 1246. 


\section{FIGURE 1}

A general model of social science explanation

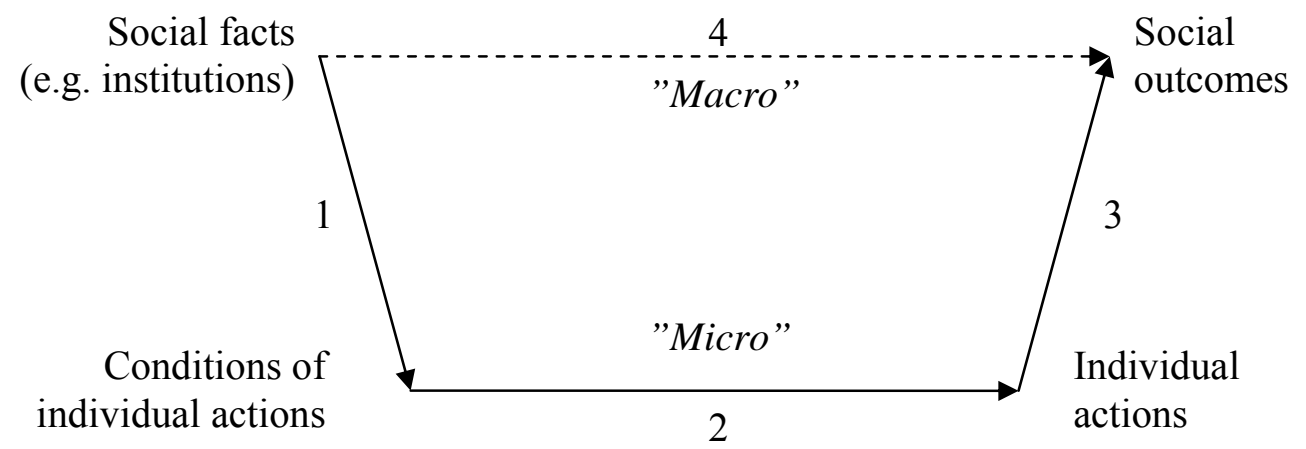


FIGURE 2

SHRM and knowledge governance

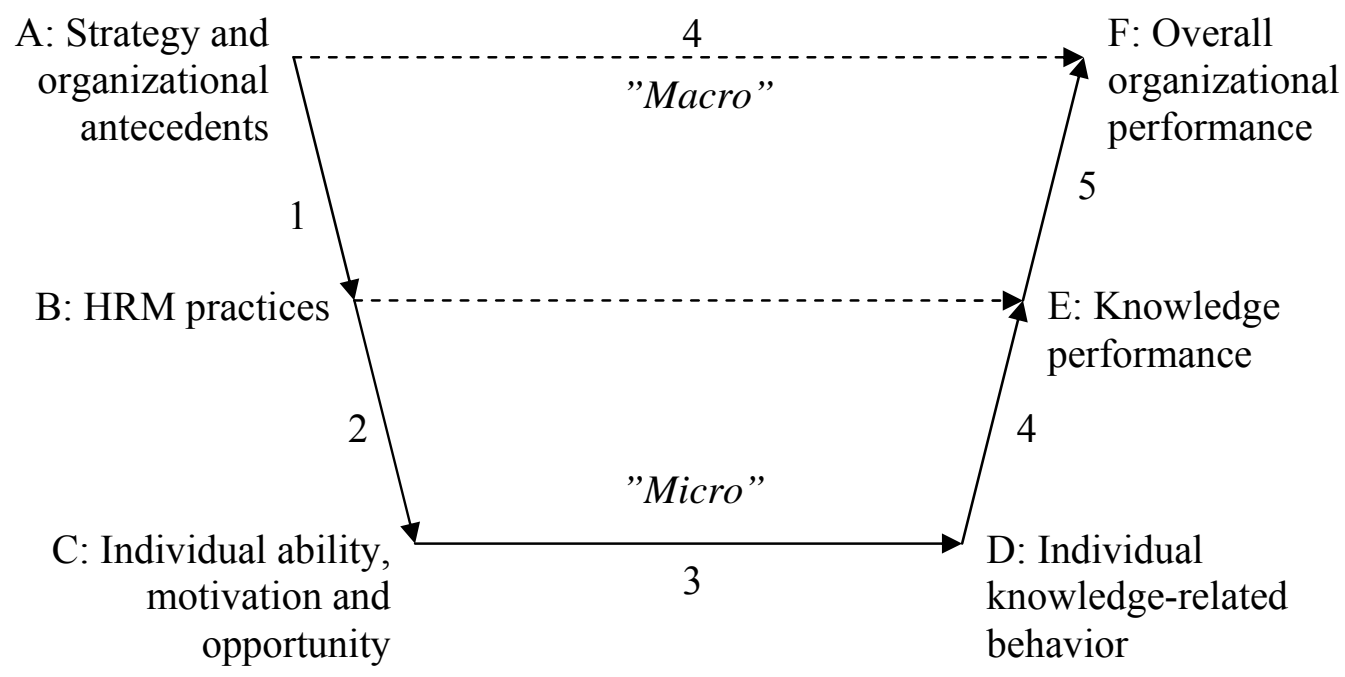


Table 1. Large- $N$ empirical research on HRM practices as explanatory variables of knowledge performance.

\begin{tabular}{|c|c|}
\hline HRM practices & Empirical studies \\
\hline \multicolumn{2}{|l|}{ Individual HRM practices } \\
\hline Job design & Cabrera, Collins and Salgado (2006); Beugelsdijk (2008) \\
\hline Recruitment and selection & $\begin{array}{l}\text { Hatch and Dyer (2004); Lopez, Peon and Ordas (2006); Gittel (2000); } \\
\text { Minbaeva (2005) }\end{array}$ \\
\hline Training & $\begin{array}{l}\text { Beugelsdijk (2008); Lopez Peon and Ordas (2006); Gomez, Lorente and } \\
\text { Cabrera (2004); Zarraga and Bonache (2003); Lyles and Salk (1996); } \\
\text { Minbaeva et al. (2003); Hatch and Dyer (2004); Minbaeva (2005) }\end{array}$ \\
\hline Job rotation & Gomez, Lorente and Cabrera (2004) \\
\hline Rewards & $\begin{array}{l}\text { Lopez, Peon and Ordas (2006); Arthur and Kim (2005); Zarraga and } \\
\text { Bonache (2003); Minbaeva et al. (2003); Cabrera, Collins and Salgado, } \\
\text { (2006); Bjorkman et al. (2004); Jerez-Gomez, Cespedes-Lorente and } \\
\text { Valle-Cabrera (2005); Persson (2006); Minbaeva (2005); Beugelsdijk } \\
\text { (2008) }\end{array}$ \\
\hline $\begin{array}{l}\text { Labor-management } \\
\text { cooperation/employee } \\
\text { involvement }\end{array}$ & $\begin{array}{l}\text { Lopez, Peon and Ordas (2006); Arthur and Kim (2005); Hatch and Dyer } \\
\text { (2004); Zarraga and Bonache (2003); Cabrera, Collins and Salgado, } \\
\text { (2006); Gittel (2000); Persson (2006); Minbaeva (2005) }\end{array}$ \\
\hline $\begin{array}{l}\text { Communication/socialization } \\
\text { practices }\end{array}$ & $\begin{array}{l}\text { Zarraga and Bonache (2003); Minbaeva et al. (2003); Gittel (2000); } \\
\text { Bjorkman et al. (2004); Persson (2006); Minbaeva (2005) }\end{array}$ \\
\hline Performance appraisal & Minbaeva et al. (2003); Bjorkman et al. (2004); Minbaeva (2005) \\
\hline Promotion & Minbaeva et al. (2003); Minbaeva (2005) \\
\hline Expatriation & $\begin{array}{l}\text { Hocking et al. (2004); Bjorkman et al. (2004); Minbaeva and Michailova } \\
(2004)\end{array}$ \\
\hline \multicolumn{2}{|l|}{ Bundles of HRM practices } \\
\hline $\begin{array}{l}\text { Commitment-based } \quad \text { HRM } \\
\text { practices }\end{array}$ & $\begin{array}{l}\text { Collins and Smith (2006): internal labor markets and selection based on } \\
\text { fit to the company; group- and organization-based incentives; and } \\
\text { training programs and performance appraisals based on long-term } \\
\text { growth, team building and development of firm specific knowledge ( } 16 \\
\text { items); }\end{array}$ \\
\hline Investment in human capital & $\begin{array}{l}\text { Jaw et al. (2006): average hours of training per person plus hours per } \\
\text { year, the rate of training hours per year and per person, the number of } \\
\text { employees who have been employed over three years divided by the } \\
\text { number of employees of a firm, the cost of payment (including salary, } \\
\text { allowance and bonus); Selvarajan et al.: reward sharing, competencies } \\
\text { development, feedback from employees, enhancing employees' }\end{array}$ \\
\hline
\end{tabular}




\begin{tabular}{|l|l|}
\hline & employability and information sharing. \\
\hline Learning-oriented HRM & $\begin{array}{l}\text { Jaw and Liu (2003): empowerment, performance emphasis, supporting } \\
\text { benefits program, comprehensive training and encouraging commitment } \\
\text { (25 items) }\end{array}$ \\
\hline $\begin{array}{l}\text { Two distinct systems of } \\
\text { complementary HRM practices, } \\
\text { which matter for the firms' } \\
\text { ability to innovate }\end{array}$ & $\begin{array}{l}\text { Laursen and Foss (2003): first (interdisciplinary workgroups, quality } \\
\text { circles, systems for collection of employees' proposals, planned job } \\
\text { rotation, delegation of responsibility, integration of functions, and } \\
\text { performance-related pay) and second (firm-internal and firm-external } \\
\text { training). }\end{array}$ \\
\hline
\end{tabular}




\section{SMG - Working Papers \\ www.cbs.dk/smg \\ 2003}

2003-1: Nicolai J. Foss, Kenneth Husted, Snejina Michailova, and Torben Pedersen: Governing Knowledge Processes: Theoretical Foundations and Research Opportunities.

2003-2: Yves Doz, Nicolai J. Foss, Stefanie Lenway, Marjorie Lyles, Silvia Massini, Thomas P. Murtha and Torben Pedersen: Future Frontiers in International Management Research: Innovation, Knowledge Creation, and Change in Multinational Companies.

2003-3: Snejina Michailova and Kate Hutchings: The Impact of In-Groups and OutGroups on Knowledge Sharing in Russia and China CKG Working Paper.

2003-4: Nicolai J. Foss and Torben Pedersen: The MNC as a Knowledge Structure: The Roles of Knowledge Sources and Organizational Instruments in MNC Knowledge Management CKG Working Paper.

2003-5: Kirsten Foss, Nicolai J. Foss and Xosé H. Vázquez-Vicente: “Tying the Manager's Hands": How Firms Can Make Credible Commitments That Make Opportunistic Managerial Intervention Less Likely CKG Working Paper.

2003-6: Marjorie Lyles, Torben Pedersen and Bent Petersen: Knowledge Gaps: The Case of Knowledge about Foreign Entry.

2003-7: Kirsten Foss and Nicolai J. Foss: The Limits to Designed Orders: Authority under "Distributed Knowledge" CKG Working Paper.

2003-8: Jens Gammelgaard and Torben Pedersen: Internal versus External Knowledge Sourcing of Subsidiaries - An Organizational Trade-Off.

2003-9: Kate Hutchings and Snejina Michailova: Facilitating Knowledge Sharing in Russian and Chinese Subsidiaries: The Importance of Groups and Personal Networks Accepted for publication in Journal of Knowledge Management.

2003-10: Volker Mahnke, Torben Pedersen and Markus Verzin: The Impact of Knowledge Management on MNC Subsidiary Performance: the Role of Absorptive Capacity CKG Working Paper.

2003-11: Tomas Hellström and Kenneth Husted: Mapping Knowledge and Intellectual Capital in Academic Environments: A Focus Group Study Accepted for publication in Journal of Intellectual Capital CKG Working Paper.

2003-12: Nicolai J Foss: Cognition and Motivation in the Theory of the Firm: Interaction or "Never the Twain Shall Meet"? Accepted for publication in Journal des Economistes et des Etudes Humaines CKG Working Paper.

2003-13: Dana Minbaeva and Snejina Michailova: Knowledge Transfer and Expatriation Practices in MNCs: The Role of Disseminative Capacity.

2003-14: Christian Vintergaard and Kenneth Husted: Enhancing Selective Capacity Through Venture Bases. 


\section{4}

2004-1: Nicolai J. Foss: Knowledge and Organization in the Theory of the Multinational Corporation: Some Foundational Issues

2004-2: Dana B. Minbaeva: HRM Practices and MNC Knowledge Transfer

2004-3: Bo Bernhard Nielsen and Snejina Michailova: Toward a Phase-Model of Global Knowledge Management Systems in Multinational Corporations

2004-4: Kirsten Foss \& Nicolai J Foss: The Next Step in the Evolution of the RBV: Integration with Transaction Cost Economics

2004-5: Teppo Felin \& Nicolai J. Foss: Methodological Individualism and the Organizational Capabilities Approach

2004-6: Jens Gammelgaard, Kenneth Husted, Snejina Michailova: Knowledge-sharing Behavior and Post-acquisition Integration Failure

2004-7: Jens Gammelgaard: Multinational Exploration of Acquired R\&D Activities

2004-8: Christoph Dörrenbächer \& Jens Gammelgaard: Subsidiary Upgrading? Strategic Inertia in the Development of German-owned Subsidiaries in Hungary

2004-9: Kirsten Foss \& Nicolai J. Foss: Resources and Transaction Costs: How the Economics of Property Rights Furthers the Resource-based View

2004-10: Jens Gammelgaard \& Thomas Ritter: The Knowledge Retrieval Matrix: Codification and Personification as Separate Strategies

2004-11: Nicolai J. Foss \& Peter G. Klein: Entrepreneurship and the Economic Theory of the Firm: Any Gains from Trade?

2004-12: Akshey Gupta \& Snejina Michailova: Knowledge Sharing in Knowledge-Intensive Firms: Opportunities and Limitations of Knowledge Codification

2004-13: Snejina Michailova \& Kate Hutchings: Knowledge Sharing and National Culture: A Comparison Between China and Russia

\section{5}

2005-1: Keld Laursen \& Ammon Salter: My Precious - The Role of Appropriability Strategies in Shaping Innovative Performance

2005-2: Nicolai J. Foss \& Peter G. Klein: The Theory of the Firm and Its Critics: A Stocktaking and Assessment

2005-3: Lars Bo Jeppesen \& Lars Frederiksen: Why Firm-Established User Communities Work for Innovation: The Personal Attributes of Innovative Users in the Case of Computer-Controlled Music

2005-4: Dana B. Minbaeva: Negative Impact of HRM Complementarity on Knowledge Transfer in MNCs

2005-5: Kirsten Foss, Nicolai J. Foss, Peter G. Klein \& Sandra K. Klein: Austrian Capital 
Theory and the Link Between Entrepreneurship and the Theory of the Firm

2005-1: Nicolai J. Foss: The Knowledge Governance Approach

2005-2: Torben J. Andersen: Capital Structure, Environmental Dynamism, Innovation Strategy, and Strategic Risk Management

2005-3: Torben J. Andersen: A Strategic Risk Management Framework for Multinational Enterprise

2005-4: Peter Holdt Christensen: Facilitating Knowledge Sharing: A Conceptual Framework

2005-5 Kirsten Foss \& Nicolai J. Foss: Hands Off! How Organizational Design Can Make Delegation Credible

2005-6 Marjorie A. Lyles, Torben Pedersen \& Bent Petersen: Closing the Knowledge Gap in Foreign Markets - A Learning Perspective

2005-7 Christian Geisler Asmussen, Torben Pedersen \& Bent Petersen: How do we Capture "Global Specialization" when Measuring Firms' Degree of internationalization?

2005-8 Kirsten Foss \& Nicolai J. Foss: Simon on Problem-Solving: Implications for New Organizational Forms

2005-9 Birgitte Grøgaard, Carmine Gioia \& Gabriel R.G. Benito: An Empirical Investigation of the Role of Industry Factors in the Internationalization Patterns of Firms

2005-10 Torben J. Andersen: The Performance and Risk Management Implications of Multinationality: An Industry Perspective

2005-11 Nicolai J. Foss: The Scientific Progress in Strategic Management: The case of the Resource-based view

2005-12 Koen H. Heimeriks: Alliance Capability as a Mediator Between Experience and Alliance Performance: An Empirical Investigation Into the Alliance Capability Development Process

2005-13 Koen H. Heimeriks, Geert Duysters \& Wim Vanhaverbeke: Developing Alliance Capabilities: An Empirical Study

2005-14 JC Spender: Management, Rational or Creative? A Knowledge-Based Discussion

\section{6}

2006-1: Nicolai J. Foss \& Peter G. Klein: The Emergence of the Modern Theory of the Firm

2006-2: Teppo Felin \& Nicolai J. Foss: Individuals and Organizations: Thoughts on a Micro-Foundations Project for Strategic Management and Organizational Analysis

2006-3: Volker Mahnke, Torben Pedersen \& Markus Venzin: Does Knowledge Sharing 
Pay? An MNC Subsidiary Perspective on Knowledge Outflows

2006-4: Torben Pedersen: Determining Factors of Subsidiary Development

2006-5 Ibuki Ishikawa: The Source of Competitive Advantage and Entrepreneurial Judgment in the RBV: Insights from the Austrian School Perspective

2006-6 Nicolai J. Foss \& Ibuki Ishikawa: Towards a Dynamic Resource-Based View: Insights from Austrian Capital and Entrepreneurship Theory

2006-7 Kirsten Foss \& Nicolai J. Foss: Entrepreneurship, Transaction Costs, and Resource Attributes

2006-8 Kirsten Foss, Nicolai J. Foss \& Peter G. Klein: Original and Derived Judgement: An Entrepreneurial Theory of Economic Organization

2006-9 Mia Reinholt: No More Polarization, Please! Towards a More Nuanced Perspective on Motivation in Organizations

2006-10 Angelika Lindstrand, Sara Melen \& Emilia Rovira: Turning social capital into business? A study of Swedish biotech firms' international expansion

2006-11 Christian Geisler Asmussen, Torben Pedersen \& Charles Dhanaraj: Evolution of Subsidiary Competences: Extending the Diamond Network Model

2006-12 John Holt, William R. Purcell, Sidney J. Gray \& Torben Pedersen: Decision Factors Influencing MNEs Regional Headquarters Location Selection Strategies

2006-13 Peter Maskell, Torben Pedersen, Bent Petersen \& Jens Dick-Nielsen: Learning Paths to Offshore Outsourcing - From Cost Reduction to Knowledge Seeking

2006-14 Christian Geisler Asmussen: Local, Regional or Global? Quantifying MNC Geographic Scope

2006-15 Christian Bjørnskov \& Nicolai J. Foss: Economic Freedom and Entrepreneurial Activity: Some Cross-Country Evidence

2006-16 Nicolai J. Foss \& Giampaolo Garzarelli: Institutions as Knowledge Capital: Ludwig M. Lachmann's Interpretative Institutionalism

2006-17 Koen H. Heimriks \& Jeffrey J. Reuer: How to Build Alliance Capabilities

2006-18 Nicolai J. Foss, Peter G. Klein, Yasemin Y. Kor \& Joseph T. Mahoney: Entrepreneurship, Subjectivism, and the Resource - Based View: Towards a New Synthesis

2006-19 Steven Globerman \& Bo B. Nielsen: Equity Versus Non-Equity International Strategic Alliances: The Role of Host Country Governance

\section{7}

2007-1 Peter Abell, Teppo Felin \& Nicolai J. Foss: Building Micro-Foundations for the Routines, Capabilities, and Performance Links 
2007-2 Michael W. Hansen, Torben Pedersen \& Bent Petersen: MNC Strategies and Linkage Effects in Developing Countries

2007-3 Niron Hashai, Christian G. Asmussen, Gabriel R.G. Benito \& Bent Petersen: Predicting the Diversity of Foreign Entry Modes

2007-4 Peter D. Ørberg Jensen \& Torben Pedersen: Whether and What to Offshore?

2007-5 Ram Mudambi \& Torben Pedersen: Agency Theory and Resource Dependency Theory: Complementary Explanations for Subsidiary Power in Multinational Corporations

2007-6 Nicolai J. Foss: Strategic Belief Management

2007-7 Nicolai J. Foss: Theory of Science Perspectives on Strategic Management Research: Debates and a Novel View

2007-8 Dana B. Minbaeva: HRM Practices and Knowledge Transfer in MNCs

2007-9 Nicolai J. Foss: Knowledge Governance in a Dynamic Global Context: The Center for Strategic Management and Globalization at the Copenhagen Business School

2007-10 Paola Gritti \& Nicolai J. Foss: Customer Satisfaction and Competencies: An Econometric Study of an Italian Bank

2007-11 Nicolai J. Foss \& Peter G. Klein: Organizational Governance

2007-12 Torben Juul Andersen \& Bo Bernhard Nielsen: The Effective Ambidextrous Organization: A Model of Integrative Strategy Making Processes.

\section{8}

2008-1 Kirsten Foss \& Nicolai J. Foss: Managerial Authority When Knowledge is Distributed: A Knowledge Governance Perspective

2008-2 Nicolai J. Foss: Human Capital and Transaction Cost Economics.

2008-3 Nicolai J. Foss \& Peter G. Klein: Entrepreneurship and Heterogeneous Capital.

2008-4 Nicolai J. Foss \& Peter G. Klein: The Need for an Entrepreneurial Theory of the Firm.

2008-5 Nicolai J. Foss \& Peter G. Klein: Entrepreneurship: From Opportunity Discovery to Judgment.

2008-6 Mie Harder: How do Rewards and Management Styles Influence the Motivation to Share Knowledge?

2008-7 Bent Petersen, Lawrence S. Welch \& Gabriel R.G. Benito: Managing the Internalisation Process - A Theoretical Perspective.

2008-8 Torben Juul Andersen: Multinational Performance and Risk Management Effects: Capital Structure Contingencies. 
2008-9 Bo Bernard Nielsen: Strategic Fit and the Role of Contractual and Procedural Governance in Alliances: A Dynamic Perspective.

2008-10 Line Gry Knudsen \& Bo Bernhard Nielsen: Collaborative Capability in R\&D Alliances: Exploring the Link between Organizational and Individual level Factors.

2008-11 Torben Juul Andersen \& Mahesh P. Joshi: Strategic Orientations of Internationalizing Firms: A Comparative Analysis of Firms Operating in Technology Intensive and Common Goods Industries.

2008-12 Dana Minbaeva: HRM Practices Affecting Extrinsic and Intrinsic Motivation of Knowledge Receivers and their Effect on Intra-MNC Knowledge Transfer.

2008-13 Steen E. Navrbjerg \& Dana Minbaeva: HRM and IR in Multinational Corporations: Uneasy Bedfellows?

2008-14 Kirsten Foss \& Nicolai J. Foss: Hayekian Knowledge Problems in Organizational Theory.

2008-15 Torben Juul Andersen: Multinational Performance Relationships and Industry Context.

2008-16 Larissa Rabbiosi: The Impact of Subsidiary Autonomy on MNE Knowledge Transfer: Resolving the Debate.

2008-17 Line Gry Knudsen \& Bo Bernhard Nielsen: Organizational and Individual Level Antecedents of Procedural Governance in Knowledge Sharing Alliances.

2008-18 Kirsten Foss \& Nicolai J. Foss: Understanding Opportunity Discovery and Sustainable Advantage: The Role of Transaction Costs and Property Rights.

2008-19 Teppo Felin \& Nicolai J. Foss: Social Reality, The Boundaries of Self-fulfilling Prophecy, and Economics.

2008-20 Yves Dos, Nicolai J. Foss \& José Santos: A Knowledge System Approach to the Multinational Company: Conceptual Grounding and Implications for Research

2008-21 Sabina Nielsen \& Bo Bernhard Nielsen: Why do Firms Employ foreigners on Their Top Management Teams? A Multi-Level Exploration of Individual and Firm Level Antecedents

2008-22 Nicolai J. Foss: Review of Anders Christian Hansen's “Uden for hovedstrømmen - Alternative strømninger i økonomisk teori"

2008-23 Nicolai J. Foss: Knowledge, Economic Organization, and Property Rights

2008-24 Sjoerd Beugelsdijk, Torben Pedersen \& Bent Petersen: Is There a Trend Towards Global Value Chain Specialization? - An Examination of Cross Border Sales of US Foreign Affiliates 
2008-25 Vikas Kumar, Torben Pedersen \& Alessandro Zattoni: The performance of business group firms during institutional transition: A longtitudinal study of Indian firms

2008-26 Sabina Nielsen \& Bo B. Nielsen: The effects of TMT and Board Nationality Diversity and Compensation on Firm Performance

2008-27 Bo B. Nielsen \& Sabina Nielsen: International Diversification Strategy and Firm Performance: A Multi-Level Analysis of Firm and Home Country Effects

\section{9}

2009-1 Nicolai J. Foss: Alternative Research Strategies in the Knowledge Movement: From Macro Bias to Micro-Foundations and Multi-Level Explanation

2009-2 Nicolai J. Foss \& Peter G. Klein: Entrepreneurial Alertness and Opportunity Discovery: Origins, Attributes, Critique

2009-3 Nicolai J. Foss \& Dana B. Minbaeva: Governing Knowledge: The Strategic Human Resource Management Dimension 